\title{
Sensitivitas dan spesifisitas lingkar pergelangan tangan sebagai prediktor obesitas dan resistensi insulin pada remaja akhir
}

\author{
Addina Rizky Fitriyanti ${ }^{1,2}$, Kusmiyati-Tjahjono ${ }^{3 *}$, M. Sulchan ${ }^{2}$, Sunarto $^{4}$
}

\begin{abstract}
Background: Obesity is one of the risk factors for insulin resistance. Insulin resistance plays an important role in the pathogenesis of cardiovascular disease. Wrist circumference has the potential for predicting obesity and insulin resistance.

Objectives:. To evaluate the sensitivity and specificity of wrist circumference against obesity and insulin resistance in late adolescents.

Methods: The design of this study is a crossectional study with a sample of 85 students at Diponegoro University Semarang. Data collected consisted of anthropometric measurements (body weight, height, wrist circumference, neck circumference, waist circumference and pelvic girth) and blood vein sampling (fasting blood glucose and fasting insulin). Statistical analyses used in this study were Pearson or $R$ Spearman correlation test.

Results: Wrist circumference was positively correlated with all biochemical parameters and anthropometric measurements except the waist hip ratio. Wrist circumference correlates positively and significantly with fasting insulin and HOMA-IR in male adolescents. The results of the ROC curve analysis showed that the AUC value of wrist circumference in male adolescents had better performance in predicting obesity (88\% (95\% CI, 76\% - 100\%)) than insulin resistance (81\% (95\% CI, 51\% - 100\%)).

Conclusion: Wrist circumference is one of the anthropometric measurements that can be used for predicting obesity and insulin resistance in late adolescents.
\end{abstract}

Keywords : sensitivity; specivity; anthropometric measurement; wrist circumference; insulin resistance

\begin{abstract}
ABSTRAK
Latar Belakang : Obesitas merupakan salah satu faktor risiko terjadinya resistensi insulin. Resistensi insulin memegang peranan penting pada patogenesis penyakit kardiovaskular. Lingkar pergelangan tangan berpotensi untuk memprediksi obesitas dan resistensi insulin.

Tujuan : Mengevaluasi sensitivitas dan spesifisitas lingkar pergelangan tangan terhadap obesitas dan resistensi insulin pada remaja akhir.

Metode : Desain penelitian ini menggunakan studi belah lintang dengan jumlah sampel 85 mahasiswa/i di Universitas Diponegoro Semarang. Data yang dikumpulkan terdiri dari pengukuran antropometri (berat badan, tinggi badan, lingkar pergelangan tangan, lingkar leher, lingkar pinggang, dan lingkar panggul) dan pengambilan sampel vena darah (kadar glukosa darah puasa dan kadar insulin puasa). Analisis yang digunakan adalah uji korelasi Pearson atau R Spearman.

Hasil : Lingkar pergelangan tangan berkorelasi positif dengan semua parameter biokimia dan pengukuran antropometri kecuali rasio pinggang panggul. Lingkar pergelangan tangan berkorelasi positif dan signifikan dengan insulin puasa dan HOMA-IR pada remaja laki-laki. Hasil analisis kurva ROC menunjukkan bahwa nilai AUC lingkar pergelangan tangan pada remaja lakilaki memiliki performa yanglebih baik dalam memprediksi obesitas (88\% (IK 95\%, 76\%-100\%)) dibanding resistensi insulin (81\% (IK 95\%, 51\%-100\%)).
\end{abstract}

Kesimpulan : Lingkar pergelangan merupakan salah satu pengukuran antropometri yang dapat digunakan untuk memprediksi obesitas dan resistensi insulin pada remaja akhir.

Kata Kunci : sensitivitas; spesifisitas; lingkar pergelangan tangan; obesitas; resistensi insulin; remaja

\section{PENDAHULUAN}

Penyakit kardiovaskular merupakan salah satu penyakit tidak menular yang menjadi masalah kesehatan penting karena berkontribusi terhadap peningkatan mortalitas baik di negara maju maupun negara berkembang. ${ }^{1,2}$ Hal yang mendasari perkembangan penyakit kardiovaskular adalah asupan zat gizi pada awal kehidupan, genetik, dan lingkungan. Distribusi lemak tubuh dianggap sebagai prediktor dari beberapa komplikasi penyakit terkait dengan obesitas. ${ }^{3}$ Obesitas adalah kondisi lemak tubuh berlebih yang

\footnotetext{
${ }^{1}$ Prodi Ilmu Gizi, Fakultas Ilmu Keperawatan dan Kesehatan, Universitas Muhammadiyah Semarang. J1 Kedungmundu Raya no 18 Tembalang, Semarang, Jawa Tengah 50273

${ }^{2}$ Departemen Ilmu Gizi, Fakultas Kedokteran, Universitas Diponegoro. Jl. Prof. Sudarto SH, Tembalang, Semarang, Jawa Tengah 50275, Indonesia

${ }^{3}$ Bagian Biokimia, Fakultas Kedokteran, Universitas Diponegoro. J1. Prof. Sudarto SH, Tembalang, Semarang, Jawa Tengah 50275, Indonesia

${ }^{4}$ Jurusan Gizi, Politeknik Kesehatan Kemenkes Semarang. Jl. Tirto Agung, Pedalangan, Kec. Banyumanik, Kota Semarang, Jawa Tengah 50268

* Korespondensi : E-mail: kusmiceria@gmail.com
} 
berkaitan dengan gaya hidup, lingkungan, dan genetik. ${ }^{4}$ Berdasarkan studi epidemiologi menunjukkan bahwa genetik dan obesitas merupakan faktor mayor dalam perkembangan diabetes mellitus tipe $2 .{ }^{5}$ Bukti menunjukkan bahwa kelebihan lemak menjadi penentu morbiditas, termasuk diantaranya hipertensi, dislipidemia, dan resistensi insulin. ${ }^{6}$ Resistensi insulin memegang peran penting dalam patogenesis penyakit kardiovaskular. ${ }^{7}$ Prevalensi resistensi insulin mengalami peningkatan, terutama pada anak-anak dan remaja yang mengalami obesitas. ${ }^{6}$ Penelitian Ling et al pada remaja Malaysia menunjukkan bahwa $33 \%$ dari 173 orang dengan overweight dan obesitas mengalami resistensi insulin. ${ }^{8}$

Penentuan resistensi insulin menggunakan hyperinsulinemic euglycemic clamp tergolong invasif dan mahal sehingga penggunaan secara klinis menjadi terbatas terutama jika digunakan pada studi epidemiologi skala besar., ${ }^{9,10}$ Penggunaan homeostasis model assessment of insulin resistance (HOMA-IR) merupakan metode skrining non invasif yang mudah. ${ }^{10}$ Tenaga kesehatan sering menggunakan pengukuran antropometri dan indeks antropometri sebagai metode alternatif untuk mengidentifikasi obesitas dan risiko kardiometabolik. ${ }^{3,11}$ Lingkar pinggang adalah salah satu antropometri yang sering digunakan untuk mengkaji gangguan metabolik. Selain itu lingkar lingkar pergelangan tangan juga dapat digunakan. ${ }^{11}$

Lingkar pergelangan tangan adalah parameter antropometri sederhana yang dapat mengkaji body frame dan ukuran tulang serta menggambarkan distribusi lemak perifer.$^{1,3,7,11,12}$ Beberapa penelitian menunjukkan bahwa peningkatan masa tulang berkaitan dengan hiperinsulinemia. ${ }^{2,3,6}$ Sinyal reseptor insulin juga berkaitan dengan proses remodeling tulang dan kontrol metabolisme tubuh. ${ }^{2,6}$ Hal ini berkaitan dengan insulin like growth factor-1 (IGF-1) yang mengatur proliferasi osteoblast, diferensiasi, dan aposisi tulang, selain itu IGF-1 memiliki 40\% kesamaan dengan struktur asam amino pada insulin. ${ }^{6}$

Hasil temuan dari beberapa penelitian mengungkapkan hasil yang tidak konsisten. Penelitian Capizzi et al menunjukkan bahwa lingkar pergelangan tangan berkorelasi positif dan signifikan terhadap insulin puasa dan HOMA-IR pada anak-anak dan remaja yang mengalami overweight/obesitas. ${ }^{6}$ Penelitian Noudeh et al menunjukkan bahwa lingkar pergelangan tangan merupakan prediktor diabetes mellitus tipe 2 yang signifikan pada dewasa baik laki-laki maupun perempuan. ${ }^{13}$ Penelitian kohort restrospektif yang dilakukan oleh Watkins et al menunjukkan bahwa pergelangan tangan remaja prepubertas bukan prediktor resistensi insulin pada masa dewasa. ${ }^{10}$

Studi berbasis populasi yang berkaitan dengan lingkar pergelangan tangan dan resistensi insulin masih terbatas sehingga diperlukan klarifikasi lebih lanjut pada etnis yang berbeda dan berbagai status gizi. Tujuan dari penelitian ini adalah untuk menentukan apakah lingkar pergelangan tangan sebagai parameter antropometri dapat digunakan untuk mengevaluasi obesitas dan resistensi insulin pada remaja.

\section{BAHAN DAN METODE}

Rancangan yang digunakan dalam penelitian ini adalah studi belah lintang. Penelitian ini dilaksanakan pada bulan Februari-Maret 2018 di Universitas Diponegoro, Semarang. Pemilihan subjek dilakukan dengan simple random sampling yang melibatkan 85 mahasiswa/i usia 17-21 tahun. Subjek yang terlibat dalam penelitian ini terdiri dari 51 perempuan dan 34 laki-laki. Kriteria inklusi pada penelitian ini adalah tidak menjalani pengobatan diabetes mellitus baik tipe 1 maupun tipe 2 atau menderita diabetes mellitus baik tipe 1 maupun tipe 2 dan bukan atlet. Subjek penelitian yang setuju terlibat dalam penelitian ini telah diminta bukti persetujuannya secara tertulis pada formulir informed consent. Penelitian ini telah mendapatkan persetujuan Ethical Clearance dari Komisi Etik Fakultas Kedokteran Universitas Diponegoro dengan No. 41/EC/FKRSDK/I/2018.

Data primer yang digunakan dalam penelitian ini meliputi: identitas subjek, data antropometri (berat badan (BB), tinggi badan (TB), lingkar pergelangan tangan, lingkar pinggang, lingkar panggul, dan lingkar leher), dan parameter biokimia (kadar glukosa darah puasa (GDP) dan kadar insulin puasa). Pengukuran antropometri dilakukan oleh tenaga terlatih dengan mengukur subjek dalam kondisi tubuh yang berdiri tegap dan rileks. Pengukuran berat badan menggunakan timbangan berat badan dengan ketelitian $0,1 \mathrm{~kg}$ sedangkan pengukuran tinggi badan menggunakan microtoise dengan ketelitian $0,1 \mathrm{~cm}$. Lingkar pergelangan tangan, lingkar leher, lingkar pinggang, dan lingkar panggul diukur menggunakan pita ukur fleksibel sebanyak dua kali oleh tenaga terlatih kemudian diratarata. Lingkar pergelangan tangan diukur pada tonjolan ulna tangan kanan. Lingkar leher diukur pada batas laring atau bagian yang paling menonjol dari tulang rawan tiroid (thyroid cartilage) untuk perempuan dan tepat dibawah laring yang menonjol (adam's apple) untuk laki-laki. Lingkar pinggang diukur pada titik tengah antara batas terbawah dari rusuk dan batas teratas dari iliaka. Lingkar panggul diukur dengan menentukan point terlebar pada pantat. Pengukuran lingkar leher, lingkar pinggang, dan lingkar panggul menggunakan pita ukur/metlin dengan ukuran maksimal $150 \mathrm{~cm}$.

Pengambilan sampel darah vena dilakukan oleh tenaga terlatih setelah subjek berpuasa selama 8-10 jam. Kadar GDP ditentukan dengan menggunakan metode hexokinase di Rumah Sakit Nasional Diponegoro Semarang dan kadar insulin puasa ditentukan dengan 
menggunakan metode enzyme-linked immunosorbent assay (ELISA) di Laboratorium GAKY Fakultas Kedokteran Universitas Diponegoro Semarang. HOMAIR dihitung berdasarkan kalkulasi antara insulin puasa dan GDP (insulin puasa ( $\mu \mathrm{IU} / \mathrm{ml})$ x GDP (mg/dl)/405).

Pengolahan dan analisis data yang digunakan dalam penelitian ini adalah statistik deskriptif dan statistik analitik. Uji Pearson atau $R$ Spearman digunakan untuk menguji korelasi antara lingkar pergelangan tangan dengan antropometri lainnya (Indeks Massa Tubuh (IMT), lingkar leher, lingkar pinggang, dan rasio pinggang panggul) dan parameter biokimia (GDP dan insulin puasa). Analisis kurva Receiver Operating Curve (ROC) digunakan untuk menentukan cut off point optimal lingkar pergelangan tangan dalam memprediksi obesitas dan resistensi insulin.

\section{HASIL}

Rerata usia subjek pada penelitian ini adalah 18,44 tahun. Berdasarkan status gizi, persentase obesitas lebih banyak dibandingkan dengan overweight, normal, dan underweight. Hasil pengukuran antropometri menunjukkan bahwa nilai rerata TB, BB, IMT, lingkar pergelangan tangan, lingkar leher, lingkar pinggang, dan lingkar panggul lebih tinggi pada laki-laki dibandingkan pada perempuan, sedangkan nilai rerata rasio pinggang panggul lebih tinggi pada perempuan dibandingkan dengan laki-laki. Nilai rerata kadar GDP pada laki-laki lebih tinggi dibandingkan dengan perempuan, sedangkan nilai rerata kadar insulin puasa dan HOMA-IR lebih tinggi pada perempuan dibandingkan dengan laki-laki. Gambaran usia, status gizi, pengukuran antropometri, dan parameter biokimia tersaji pada Tabel 1.

Tabel 1. Gambaran Usia, Antropometri, dan Parameter Biokimia

\begin{tabular}{|c|c|c|c|c|}
\hline \multirow{2}{*}{ Usia } & \multirow{2}{*}{$\begin{array}{c}\begin{array}{c}\text { Total } \\
(\mathbf{n}=\mathbf{8 5})\end{array} \\
18,44 \pm 0,645^{\mathrm{a}}\end{array}$} & $\begin{array}{c}\text { Laki-laki } \\
(n=34)\end{array}$ & \multicolumn{2}{|c|}{$\begin{array}{c}\text { Perempuan } \\
(\mathrm{n}=51)\end{array}$} \\
\hline & & $18,38 \pm 0,652^{\mathrm{a}}$ & \multicolumn{2}{|c|}{$18,47 \pm 0,644^{\mathrm{a}}$} \\
\hline \multicolumn{5}{|l|}{ Status Gizi } \\
\hline Underweight $\left(\leq 18,49 \mathrm{~kg} / \mathrm{m}^{2}\right)$ & $18(21,2 \%)$ & $7(20,6 \%)$ & \multicolumn{2}{|c|}{$11(21,6 \%)$} \\
\hline Normal $\left(18,5-22,9 \mathrm{~kg} / \mathrm{m}^{2}\right)$ & $21(24,7 \%)$ & $10(29,4 \%)$ & \multicolumn{2}{|c|}{$11(21,6 \%)$} \\
\hline Overweight $\left(23-24,9 \mathrm{~kg} / \mathrm{m}^{2}\right)$ & $21(24,7 \%)$ & $6(17,6 \%)$ & \multicolumn{2}{|c|}{$15(29,4 \%)$} \\
\hline Obesitas $\left(\geq 25 \mathrm{~kg} / \mathrm{m}^{2}\right)$ & $25(29,4 \%)$ & $11(32,4 \%)$ & \multicolumn{2}{|c|}{$14(27,5 \%)$} \\
\hline \multicolumn{5}{|l|}{ Antropometri } \\
\hline Tinggi badan $(\mathrm{cm})$ & $160,08 \pm 9,215^{\mathrm{a}}$ & $169,38 \pm 6,340^{\mathrm{a}}$ & \multicolumn{2}{|c|}{$153,88 \pm 4,25^{\mathrm{a}}$} \\
\hline Berat badan $(\mathrm{kg})$ & $60,15 \pm 15,448^{\mathrm{a}}$ & $67,99 \pm 16,945^{\mathrm{a}}$ & \multicolumn{2}{|c|}{$54,92 \pm 11,903^{\mathrm{a}}$} \\
\hline $\operatorname{IMT}\left(\mathrm{kg} / \mathrm{m}^{2}\right)$ & $23,22 \pm 5,078^{a}$ & $23,62 \pm 5,398^{a}$ & \multicolumn{2}{|c|}{$23,17 \pm 4,763^{\mathrm{a}}$} \\
\hline Lingkar pergelangan tangan $(\mathrm{cm})$ & $15,10 \pm 1,263^{\mathrm{a}}$ & $15,84 \pm 1,083^{\mathrm{a}}$ & \multicolumn{2}{|c|}{$14,61 \pm 1,135^{\mathrm{a}}$} \\
\hline Lingkar leher $(\mathrm{cm})$ & $32(27,35-39,30)^{\mathrm{b}}$ & $33,87(29,70-39,30)^{\mathrm{b}}$ & \multicolumn{2}{|c|}{$30(27,35-36,50)^{\mathrm{b}}$} \\
\hline Lingkar pinggang (cm) & $76,18 \pm 10,208^{a}$ & $78,23 \pm 10,276^{\mathrm{a}}$ & \multicolumn{2}{|c|}{$74,82 \pm 9,309^{a}$} \\
\hline Lingkar panggul $(\mathrm{cm})$ & $89,91 \pm 11,615^{\mathrm{a}}$ & $97,51 \pm 10,276^{\mathrm{b}}$ & \multicolumn{2}{|c|}{$84,84 \pm 9,562^{\mathrm{a}}$} \\
\hline Rasio Pinggang Panggul & $0,84 \pm 0,066^{\mathrm{a}}$ & $0,80 \pm 0,481^{\mathrm{a}}$ & & $0,056^{\mathrm{a}}$ \\
\hline Parameter Biokimia & & & & \\
\hline GDP (mg/dL) & $86(70-327)^{\mathrm{b}}$ & $89(77-103)^{\mathrm{b}}$ & & $-327)^{b}$ \\
\hline Insulin Puasa $(\mu \mathrm{IU} / \mathrm{ml})$ & $6,69(0,32-22,94)^{b}$ & $5,82(1,77-22,94)^{\mathrm{b}}$ & 7,24 & $-22,32)^{b}$ \\
\hline HOMA-IR & $1,45(0,06-5,61)^{\mathrm{b}}$ & $1,26(0,38-5,61)^{\mathrm{b}}$ & 1,52 & $6-4,70)^{b}$ \\
\hline $\begin{array}{l}\text { Keterangan: }{ }^{\mathrm{a}}: \text { rerata } \pm \text { standar baku, }{ }^{\mathrm{b}}: \text { mediar } \\
\text { Assessment Of Insulin Resistance }\end{array}$ & imal); IMT: Indeks Mas & GDP: Glukosa Darah Puas & asa, $\mathrm{HOI}$ & eostasis Mc \\
\hline & Laki-la & & Peren & \\
\hline & Korelasi (r) & Sig. $(p)$ & Korelasi $(\mathbf{r})$ & Sig. $(p)$ \\
\hline IMT $\left(\mathrm{kg} / \mathrm{m}^{2}\right)$ & $0,611^{\mathrm{a}}$ & 0,00 & $0,619^{\mathrm{a}}$ & 0,00 \\
\hline Lingkar leher $(\mathrm{cm})$ & $0,729^{b}$ & 0,00 & $0,520^{\mathrm{b}}$ & 0,00 \\
\hline Lingkar pinggang $(\mathrm{cm})$ & $0,628^{\mathrm{a}}$ & 0,00 & $0,598^{\mathrm{a}}$ & 0,00 \\
\hline Lingkar panggul $(\mathrm{cm})$ & $0,767^{\mathrm{a}}$ & 0,00 & $0,628^{\mathrm{a}}$ & 0,00 \\
\hline Rasio Pinggang Panggul & $-0,204^{\mathrm{a}}$ & 0,06 & $0,061^{\mathrm{a}}$ & 0,67 \\
\hline $\mathrm{GDP}(\mathrm{mg} / \mathrm{dl})$ & $0,290^{\mathrm{b}}$ & 0,09 & $-0,148^{b}$ & 0,29 \\
\hline Insulin puasa $(\mu \mathrm{IU} / \mathrm{ml})$ & $0,358^{\mathrm{b}}$ & 0,03 & $0,039^{\mathrm{b}}$ & 0,78 \\
\hline HOMA-IR & $0,373^{\mathrm{b}}$ & 0,03 & $0,012^{\mathrm{b}}$ & 0,93 \\
\hline
\end{tabular}

Keterangan: a ${ }^{\text {: Pearson, }}{ }^{\text {b: }}$ R Spearman; IMT: Indeks Massa Tubuh, GDP: Glukosa Darah Puasa, HOMA-IR: Homeostasis Model Assessment Of Insulin Resistance 
Tabel 3. Cut off Point Optimal Lingkar Pergelangan Tangan dalam Mendeteksi Obesitas dan Resistensi Insulin Berdasarkan Analisis Receiver Operating Curve

\begin{tabular}{lccccc}
\hline & Cut off point $(\mathbf{c m})$ & Se (\%) & Sp (\%) & AUC (IC 95\%) & $\boldsymbol{p}$ \\
\hline Obesitas & & & & & \\
Laki-laki & $\geq 16,02$ & 81,8 & 82,6 & $88(76-100)$ & 0,00 \\
Perempuan & $\geq 14,57$ & 64,3 & 64,9 & $70(52-88)$ & 0,02 \\
Resistensi Insulin & & & & & \\
Laki-laki & $\geq 16,07$ & 66,7 & 67,7 & $81(51-100)$ & 0,07 \\
Perempuan & $\geq 14,42$ & 50 & 51 & $70(00-61)$ & 0,32 \\
\hline
\end{tabular}

Hasil analisis statistik menunjukkan bahwa lingkar pergelangan tangan berkorelasi positif dengan semua parameter biokimia dan pengukuran antropometri kecuali rasio pinggang panggul baik pada laki-laki maupun perempuan. Korelasi antara lingkar pergelangan tangan dengan antropometri yang lain dan parameter biokimia menurut jenis kelamin disajikan dalam Tabel 2 . Lingkar pergelangan tangan memiliki korelasi positif dan signifikan terhadap IMT, lingkar leher, lingkar pinggang, dan lingkar panggul. Nilai cut off point optimal, sensitivitas, spesitivitas, dan nilai AUC lingkar pergelangan tangan dalam memprediksi obesitas dan resistensi insulin tersaji dalam Tabel 3.

\section{PEMBAHASAN}

Risiko kardiometabolik secara umum telah digunakan untuk mendeskripsikan risiko menyeluruh dari perkembangan penyakit kardiovaskular. Obesitas dan overweight berkaitan dengan peningkatan risiko kardiometabolik. ${ }^{14}$ Perkembangan pubertas dan hormon seksual berpengaruh terhadap komposisi tubuh. Selama masa pubertas laki-laki memiliki massa tubuh bebas lemak dan massa tulang yang lebih besar dibanding perempuan. ${ }^{15}$ Peningkatan lemak gluteofemoral pada tubuh bagian paha dan pantat menyebabkan perempuan memiliki bentuk tubuh gynoid, sedangkan pada laki-laki mengalami peningkatan lemak trunkal, lemak visceral, dan lemak hepar pada abdomen yang menyebabkan lakilaki memiliki bentuk tubuh android. ${ }^{16,17}$ Perempuan mengalami overweight atau obesitas setelah usinya mencapai 45 tahun, sedangkan laki-laki mengalami overweight/obesitas ketika usia muda. ${ }^{16}$ Oleh karena itu laki-laki memiliki lingkar pinggang dan lingkar panggul yang lebih besar dibanding perempuan.

Beberapa penelitian telah menunjukkan bahwa skeleton tidak hanya berfungsi sebagai kerangka struktur tubuh, tetapi juga organ endokrin yang mengatur beberapa proses metabolisme. Hormon osteokalsin memegang peranan penting dalam metabolisme energi, terutama pada metabolisme glukosa ${ }^{18}$. Lingkar pergelangan tangan dianggap sebagai parameter antropometri yang dapat menentukan body frame dan ukuran tulang yang dapat diukur dengan mudah. Peningkatan masa tulang berkaitan dengan peningkatan massa lemak tubuh. ${ }^{17}$ Peningkatan massa tulang juga berkaitan dengan hiperinsulinemia. Hal ini berkaitan dengan reseptor insulin yang mengkomunikasikan proses remodeling tulang melalui kontrol metabolisme tubuh. ${ }^{2,3,6,19}$ Hasil penelitian ini menunjukkan bahwa lingkar pergelangan tangan pada remaja usia 18 tahun berkorelasi positif dengan insulin puasa dan HOMA-IR pada jenis kelamin laki-laki maupun perempuan.

Perbedaan korelasi antara jenis kelamin terhadap lingkar pergelangan tangan dan resistensi insulin dapat disebabkan oleh hormon steroid sex yang berkaitan dengan metabolisme tulang dan homeostasis glukosa. ${ }^{13}$ Penelitian secara in vitro menunjukkan bahwa kemungkinan insulin memiliki efek anabolik terhadap pembentukan tulang melalui rangsangan proliferasi osteoblast dan menghambat proliferasi osteoklas. Insulin dan IGF-1 memiliki struktur asam amino yang mirip sehingga memungkinkan terjadinya ikatan antara insulin dan IGF-1 dengan reseptor sel membran maupun sebaliknya. IGF-1 dikenal sebagai pengatur pertumbuhan tulang pada masa kanak-kanak. ${ }^{3,6,20}$

Hasil penelitian ini menunjukkan bahwa lingkar pergelangan tangan memiliki performa yang baik sebagai penanda obesitas pada jenis kelamin laki-laki dengan nilai sensitivitas $81,8 \%$ dan spesifisitas $82,6 \%$. Nilai sensitivitas yang tinggi $(81,8 \%)$ cocok digunakan untuk skrining sehingga dapat memperoleh subjek yang mengalami obesitas. Nilai AUC lingkar pergelangan tangan yang diperoleh dari metode ROC adalah sebesar $88 \%$. Secara statistik, nilai AUC sebesar $88 \%$ tergolong kuat. $^{21}$

Penelitian yang dilakukan oleh Shafiee et al. pada 13.486 pelajar usia 6-18 tahun menunjukkan bahwa lingkar pergelangan tangan berkorelasi positif dan signifikan dengan berat badan, tinggi badan, IMT, lingkar pinggang, lingkar panggul, serta rasio lingkar pinggang dan tinggi badan baik pada laki-laki maupun perempuan. Berdasarkan hasil penelitian tersebut, lingkar pergelangan tangan memiliki performa yang baik dalam mengklasifikasikan subjek dalam kategori overweight (AUC: 0,67-0,75, p<0,001), obesitas (AUC: 0,81-0,85, $\mathrm{p}<0,001$ ), dan obesitas abdominal (AUC: $0,82-0,87, \mathrm{p}<0,001) .{ }^{1}$ Secara statistik interpretasi nilai AUC $>0,8-0,9$ tergolong baik. ${ }^{21}$

Penelitian Younes et al. pada orang dewasa usia $\geq 20$ tahun sebanyak 6393 subjek dengan melakukan follow up selama 8,8 tahun dan diperiode tersebut 
sebanyak 649 mengalami diabetes mellitus yang terdiri dari 269 laki-laki dan 380 perempuan. Berdasarkan hasil penelitian tersebut menunjukkan bahwa lingkar pergelangan tangan merupakan prediktor yang signifikan terhadap diabetes mellitus dan sindrom metabolik. Selain itu prediktabilitas dari lingkar pergelangan tangan merupakan indikator obesitas yang baik terutama pada perempuan. Hasil penelitian tersebut juga menyatakan bahwa prediksi insidensi diabetes mellitus berdasarkan lingkar pergelangan tangan dengan cut off point optimal $15,7 \mathrm{~cm}$ pada perempuan memiliki nilai sensitifitas $80,6 \%$ dan spesifitas $53,0 \% .{ }^{13}$

Penelitian Christian et. al. pada 384 penderita diabetes mellitus dengan usia 50 tahun menunjukkan bahwa lingkar pergelangan tangan pada jenis kelamin perempuan memiliki korelasi yang signifikan terhadap sindrom metabolik dan hipertensi. Hasil penelitian tersebut mengemukakan bahwa lingkar pergelangan tangan merupakan prediktor sindrom metabolik dan hipertensi yang signifikan pada perempuan setelah dikontrol usia, durasi terdiagnosa diabetes, riwayat hipertensi, dan umur. Cut off point optimal lingkar pergelangan tangan dalam mengidentifikasi individu yang mengalami peningkatan risiko kardiometabolik $17,5-17,8 \mathrm{~cm}$ untuk laki-laki dan 16,0-16,6 cm untuk perempuan. $^{14}$

Penelitian Banu et al. pada 136 pasien rawat jalan di klinik endokrinologi dan metabolisme Universitas Uludag, Turki dengan usia 18-75 tahun menunjukkan bahwa lingkar pergelangan tangan memiliki korelasi yang positif dengan parameter pengukuran obesitas yang lain seperti berat badan, IMT, lingkar leher, lingkar pinggang, rasio pinggang panggul, selain itu lingkar pergelangan tangan juga memiliki korelasi positif dengan kadar insulin puasa dan HOMAIR hanya pada subjek perempuan. Lingkar pergelangan tangan dapat dijadikan parameter pengukuran obesitas dan resistensi insulin yang menjadi salah satu faktor perkembangan diabetes, sindrom metabolik, dan penyakit kardiovaskular. ${ }^{22}$

Strategi pencegahan yang lebih efektif dalam memprediksi faktor risiko dan diagnosis awal resistensi insulin dapat membantu mengurangi kejadian penyakit metabolik yang memberikan beban besar pada sistem pelayanan kesehatan. $^{19}$ Beberapa pengukuran antropometri digunakan sebagai tanda yang dapat mencerminkan obesitas dan prediktor risiko kardiometabolik. ${ }^{3}$ Prediksi faktor risiko kardiometabolik menggunakan IMT masih sering diragukan karena tidak dapat membedakan lemak dari massa otot dan tidak dapat mengindikasikan distribusi lemak tubuh. Beberapa penelitian mengemukakan bahwa penggunaan parameter antropometri seperti lingkar pinggang, rasio pinggang panggung, dan rasio lingkar pinggang terhadap tinggi badan berkaitan dengan risiko kardiometabaolik. Namun antropometri tersebut tidak mudah untuk penelitian skala besar dan memungkinkan terjadinya kesalahan dalam penentuan titik ukur. Oleh karena itu perlu dipertimbangkan pengukuran antropometri yang lebih sederhana seperti lingkar pergelangan tangan. ${ }^{3}$

Lingkar pergelangan tangan mencerminkan tulang pada area pergelangan tangan, distribusi dan metabolisme lemak perifer sehingga dapat mengukur body frame dan ukuran tulang dengan mudah. $3,11,19,20,23$ Lingkar pergelangan tangan memiliki keuggulan dibandingkan dengan antropometri yang lain, yaitu murah, non invasif, sederhana, mudah diterima, nyaman bagi pemeriksa dan responden, titik ukur jelas, dan ukurannya tidak berubah sepanjang hari. ${ }^{7111,19,23}$ Pengukuran lingkar pergelangan tangan dapat memberikan kemudahan dalam memprediksi tanda klinis dari resistensi insulin terutama pada remaja obesitas yang memiliki peningkatan risiko terhadap penyakit kardiovaskular. ${ }^{7}$

Keterbatasan dalam penelitian ini adalah rancangan studi belah lintang sehingga hubungan kausalitas tidak dapat teridentifikasi. Penelitian selanjutnya perlu mempertimbangkan pemilihan subjek dengan overweight dan obesitas sehingga dapat dilihat dampaknya terhadap peningkatan kadar insulin puasa dan kondisi resistensi insulin baik pada anak-anak, remaja, maupun dewasa.

\section{SIMPULAN}

Lingkar pergelangan merupakan salah satu pengukuran antropometri yang dapat digunakan untuk memprediksi obesitas pada remaja. Lingkar pergelangan tangan pada laki-laki memiliki nilai sensitivitas dan spesifisitas yang lebih unggul dibanding perempuan dalam memprediksi obesitas. Lingkar pergelangan tangan dalam memprediksi resistensi insulin memiliki nilai sensitivitas dan spesifisitas yang rendah baik pada perempuan maupun laki-laki.

\section{DAFTAR PUSTAKA}

1. Shafiee G, Qorbani M, Heshmat R, Djalalinia S, Motlagh ME, Arefirad T, et al. Wrist circumference as a novel predictor of obesity in children and adolescents: The CASPIAN-IV study. J Pediatr Endocrinol Metab. 2018;31(7):717-725.

2. Hajsadeghi S, Firouzi A, Bahadoran $P$, Hassanzadeh M. The value of wrist circumference for predicting the presence of coronary artery disease and metabolic syndrome. Indian Heart $\mathbf{J}$. 2016;68:S5-9.

3. Kelishadi R, Heidari-Beni M, Qorbani M, Motamed-Gorji N, Motlagh ME, Ziaodini H, et al. Association between neck and wrist circumferences and cardiometabolic risk in children and adolescents: The CASPIAN-V study. Nutrition. 
2017;43-44:32-8.

4. Lysen LK, Donna A. Israel. Nutrition in Weight Management. In: Mahan LK, Raymond JL, editors. Krause's Food and The Nutrition Care Process. 14th editi. Canada: Elsevier Inc. 2017. p. 383-402.

5. Amini A, Soltanian N, Iraj B, Askari G, Ebneyamin $\mathrm{S}$, Ghias $\mathrm{M}$, et al. Original article association of wrist circumference with cardio metabolic risk factors statistical analysis: J Pak Med Assoc. 2012;62(3 suppl 2):34-6.

6. Capizzi M, Leto G, Petrone A, Zampetti S, Papa RE, Osimani $\mathrm{M}$, et al. Wrist circumference is a clinical marker of insulin resistance in overweight and obese children and adolescents. Circulation. 2011;123:1757-62.

7. Campagna G, Zampetti S, Gallozzi A, Giansanti S, Chiesa C, Pacifico L, et al. Excellent intra and interobserver reproducibility of wrist circumference measurements in obese children and adolescents. PLoS One. 2016;11(6):1-10.

8. Ling JCY, Mohamed MNA, Jalaludin MY, Rampal S, Zaharan NL, Mohamed Z. Determinants of high fasting insulin and insulin resistance among overweight/obese adolescents. Sci Rep. 2016;6(October):1-10.

9. Mitrea A, Soare A, Popa SG, Tudor MN, Mota M, Pozzilli P. Wrist circumference: An independent predictor of both insulin resistance and chronic kidney disease in an elderly population. Rom $\mathbf{J}$ Diabetes, Nutr Metab Dis. 2013;20(3):323-9.

10. Watkins AN, Kelly AS, Prineas RJ, Marlatt KL, Dengel DR, Sinaiko AR, et al. Childhood wrist circumference is not a predictor of insulin resistance in adulthood. J Pediatr. 2015;166(4):1085-7.

11. Öztürk A, Çiçek B, Mazıcıoğlu MM, Zararsız G, Kurtoğlu S. Wrist circumference and frame size percentiles in 6-17-year-old Turkish children and adolescents in Kayseri. J Clin Res Pediatr Endocrinol. 2017;9(4):329-36.

12. Derakhshan A, Eslami A, Bozorgmanesh M, Sheikholeslami F, Azizi F, Hadaegh F. Wrist circumference as a novel negative risk factor for cardiovascular disease among adult men: a median follow-up of 9 years. $\mathrm{J}$ Endocrinol Invest. 2016;39(7):763-8.

13. Noudeh YJ, Hadaegh F, Vatankhah N, Momenan AA, Saadat N, Khalili D, et al. Wrist circumference as a novel predictor of diabetes and prediabetes: Results of cross-sectional and 8.8-year follow-up studies. J Clin Endocrinol Metab. 2013;98(2):777-
84.

14. Obirikorang $\mathrm{C}$, Obirikorang $\mathrm{Y}$, Acheampong E, Anto EO, Toboh E, Asamoah EA, et al. Association of wrist circumference and waist-to-height ratio with cardiometabolic risk factors among type II diabetics in a Ghanaian population. J Diabetes Res. 2018;1-11.

15. Newbern D, Gumus Balikcioglu P, Balikcioglu M, Bain J, Muehlbauer M, Stevens R, et al. Sex Differences in biomarkers associated with insulin resistance in obese adolescents: metabolomic profiling and principal components analysis. J Clin Endocrinol Metab. 2014;99(12):4730-9.

16. Kautzky-Willer A, Harreiter J, Pacini G. Sex and gender differences in risk, pathophysiology and complications of type 2 diabetes mellitus. Endocr Rev. 2016;37(3):278-316.

17. Garza FJG la, Ayala AEG, Nava MG, Monsivais LIM, Martinez AMS, Lopez ER, et al. Body frame size in school children is related to the amount of adipose tissue in different depots but not to adipose distribution. Am J Hum Biol. 2017;1-7.

18. Shao J, Wang Z, Yang T, Ying H, Zhang Y, Liu S. Bone regulates glucose metabolism as an endocrine organ through osteocalcin. Int $\mathrm{J}$ Endocrinol. 2015;1-9.

19. Namazi N, Djalalinia S, Mahdavi A, Hamid G, Morteza A. Association of wrist circumference with cardio-metabolic risk factors: a systematic review and meta-analysis. Eat Weight Disord - Stud Anorexia, Bulim Obes. 2018;1-11.

20. Mohebi R, Mohebi A, Sheikholeslami F, Azizi F, Hadaegh F. Wrist circumference as a novel predictor of hypertension and cardiovascular disease : results of a decade follow up in a West Asian cohort. J Am Soc Hypertens. 2014;8(11):800-7.

21. Dahlan MS. Analisis Penelitian Diagnostik. In: Penelitian Diagnostik. Jakarta: Salemba Medika; 2009. p. 20-30.

22. Tatar BT, Ersoy C, Kacan T, Kirhan E, Sarandol E. Neck and wrist circumferences propose a reliable approach to qualify obesity and insulin resistance. Med Sci. 2014;3(1):1013-25.

23. Khadilkar V, Chiplonkar S, Ekbote V, Kajale N, Mandlik R. Reference centile curves for wrist circumference for Indian children aged 3-18 years. J Pediatr Metab. 2018;91(20):1-6. 